\title{
Targeting Neurotrophins to Specific Populations of Neurons: NGF, BDNF, and NT-3 and Their Relevance for Treatment of Spinal Cord Injury
}

\author{
Kathleen M. Keefe ${ }^{*, t}$, Imran S. Sheikh ${ }^{*}{ }^{\dagger}$ and George M. Smith \\ Shriners Hospital's Pediatric Research Center (Center for Neural Repair and Rehabilitation), \\ Lewis Katz School of Medicine at Temple University, 6th Floor Medical Education \& Research Building, \\ 3500 N. Broad Street, Philadelphia, PA 19140-4106, USA; tue44530@temple.edu \\ * Correspondence: kathymkeefe@temple.edu (K.M.K.); sheikh@temple.edu (I.S.S.); \\ Tel.: +1-215-926-9330 (K.M.K. \& I.S.S.) \\ + These authors contributed equally to this work.
}

Academic Editors: Margaret Fahnestock and Keri Martinowich

Received: 21 December 2016; Accepted: 24 February 2017; Published: 3 March 2017

\begin{abstract}
Neurotrophins are a family of proteins that regulate neuronal survival, synaptic function, and neurotransmitter release, and elicit the plasticity and growth of axons within the adult central and peripheral nervous system. Since the 1950s, these factors have been extensively studied in traumatic injury models. Here we review several members of the classical family of neurotrophins, the receptors they bind to, and their contribution to axonal regeneration and sprouting of sensory and motor pathways after spinal cord injury (SCI). We focus on nerve growth factor (NGF), brain derived neurotrophic factor (BDNF), and neurotrophin-3 (NT-3), and their effects on populations of neurons within diverse spinal tracts. Understanding the cellular targets of neurotrophins and the responsiveness of specific neuronal populations will allow for the most efficient treatment strategies in the injured spinal cord.
\end{abstract}

Keywords: spinal cord injury; neurotrophic factors; nerve growth factor; brain-derived neurotrophic factor; neurotrophin-3; neuroprotection; plasticity; regeneration

\section{Introduction}

In the adult central nervous system, axons fail to regenerate after injury. This lack of regeneration can be attributed to diminished activation of intrinsic growth programs, and a local environment that both lacks growth permissive molecules and contains many growth inhibitory molecules. Even when axons are able to regenerate, they rarely target the correct post-synaptic neurons or form synaptic connections that restore function. An optimal environment for regeneration would include a heightened internal growth state and the presence of molecules that can overcome inhibitory influences to guide axons to appropriate targets, and induce growth only of lesioned neuronal populations, without effecting non-injured populations. In addition, as locomotion and other movement requires multiple motor and sensory pathways for proper integration and re-establishment of movement patterning, growth and connection of multiple neuronal populations may be needed to drive significant functional recovery.

During development, growth-permissive neurotrophic factors allow axons to lengthen and extend towards appropriate targets in the correct numbers. There are currently more than 50 known factors that direct axonal growth and guidance, synapse formation, and pruning of axons and dendrites during development. In the adult, these factors contribute to neuronal survival, axonal plasticity, and synaptic function, including neurotransmitter availability [1-9]. However, the expression of many 
neurotrophic factors is greatly reduced within the adult central nervous system (CNS). Exogenous application of these factors has the potential to create a growth permissive environment after an injury. Here we focus on three factors described as the "classic" neurotrophin family: nerve growth factor (NGF), brain derived neurotrophic factor (BDNF), and neurotrophin-3 (NT-3), and their therapeutic potential for spinal cord injury.

The members of the classical neurotrophin family are structurally similar proteins. They are manufactured as larger, precursor proteins called proneurotrophins, which consist of an N-terminal prodomain and a C-terminal mature domain [10]. The pro-forms, which were once thought only to influence folding of the mature protein, are now recognized as biologically active molecules that may complement or oppose the activity of the mature forms. Mature neurotrophins are created when the pro-forms are cleaved and form non-covalently linked homodimers. Proneurotrophins can either be cleaved intracellularly by furin or proconvertase, and then secreted, or they may be processed extracellularly by plasmin, matrix metalloproteinase-3 (MMP-3), or matrix metalloproteinase-7 (MMP-7) [11-16]. These homodimers bind to two main classes of receptors-tropomyosin receptor kinase (Trk) receptors and pan neurotrophin $\left(p 75^{\mathrm{NTR}}\right)$ receptors (Figure 1). All members of the family bind with low affinity to the $\mathrm{p} 75^{\mathrm{NTR}}$ receptor. This receptor contains four cysteine-rich repeats (CR1-4). CR2 and CR3 have been implicated as binding sites for neurotrophins [17,18]. The individual neurotrophins bind specifically and with high affinity to Trk receptors, with NGF binding to TrkA, BDNF binding to TrkB, and NT-3 binding to TrkC [19-21]. Low affinity NT-3 binding to TrkA and TrkB has also been demonstrated in vitro in neuronal contexts [22,23]. Binding interactions mainly occur in the immunoglobin-like domains (Ig1 and Ig2) of the Trk receptors [21].

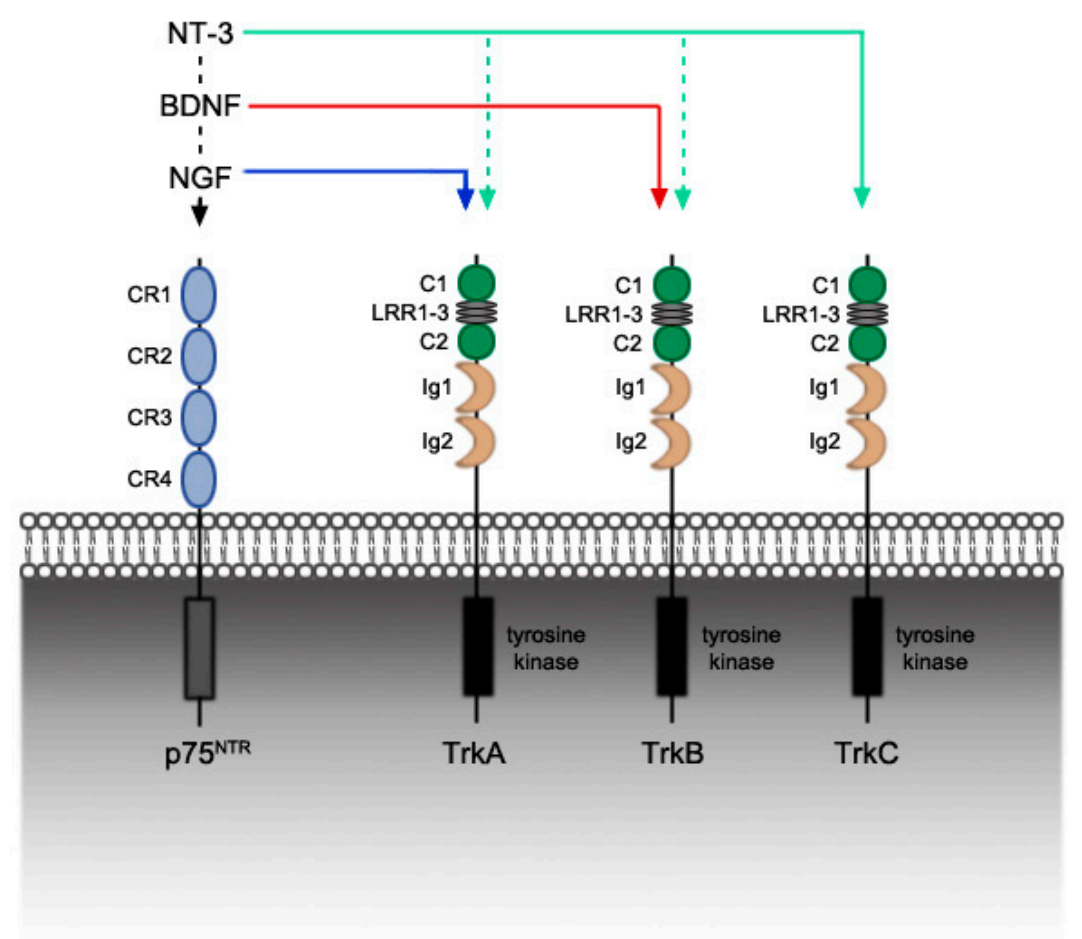

Figure 1. Neurotrophin binding to pan neurotrophin ( $75^{\mathrm{NTR}}$ ) and tropomyosin receptor kinase (Trk) receptors. All neurotrophins bind with low affinity to the $\mathrm{p} 75^{\mathrm{NTR}}$ receptor. Nerve growth factor (NGF) binds with high affinity to TrkA, and brain derived neurotrophic factor (BDNF) with high affinity to TrkB. Neurotrophin-3 (NT-3) binds with high affinity to TrkC, and may bind with low affinity to TrkA or TrkB depending on the cellular context. CR: cysteine-rich repeat, C: cysteine-rich cluster, LRR: leucine-rich repeat, Ig: Immunoglobin-like domain. Solid lines denote high affinity binding, dashed lines denote low affinity binding. 
Neurotrophin binding to Trk receptors causes receptor dimerization and autophosphorylation of tyrosine residues, ultimately leading to activation of downstream signaling cascades. Several cascades known to be activated or upregulated are phosphatidylinositol 3-kinase (PI3K)/protein kinase B (Akt), Ras/mitogen-activated protein kinase (Ras/MAPK), and phospholipase C- $\gamma$ (PLC- $\gamma$ ). These pathways have known roles in neuronal survival, axonal outgrowth, and synaptic plasticity [24]. Binding to Trk receptors is influenced by the $\mathrm{p} 75^{\mathrm{NTR}}$ in a number of ways. P75 ${ }^{\mathrm{NTR}}$ can promote ligand binding to Trk receptors by influencing the confirmation of the receptor, which can increase the affinity of the "preferred" neurotrophin and decrease binding of others [25-27]. Several studies have shown that neurotrophins such as NGF require the presence of $\mathrm{p} 75^{\mathrm{NTR}}$ for high affinity binding to TrkA [28]. $\mathrm{p} 75^{\mathrm{NTR}}$ can also promote endocytosis and retrograde transport of neurotrophins to membrane compartments where they can interact with Trk receptors [29-31], and may reduce Trk ubiquitination, which can delay the internalization and degradation of the receptors, allowing for longer signaling periods [30]. Additionally, $\mathrm{P} 75^{\mathrm{NTR}}$ can activate pro-survival pathways such as Akt to act synergistically with Trk-mediated neurotrophin effects [32].

Activation of $\mathrm{p} 75^{\mathrm{NTR}}$ receptors can also operate in an antagonistic manner to cell survival and growth, triggering several potential pro-apoptotic cascades. In the absence of Trk, mature neurotrophin binding to $p 75^{\mathrm{NTR}}$ can activate Jun N-terminal (JNK) kinases, which trigger cell death via activation of p53 [19,33]. JNK activation has specifically been shown to operate in an NGF-dependent manner during p $75^{\text {NTR }}$-mediated cell death in cortical oligodendrocytes [34]. In sympathetic neurons, $p 75^{\mathrm{NTR}}$ can trigger a pro-apoptotic cascade via binding with BDNF through a JNK-independent mechanism [35]. Recent studies of proneurotrophins reveal that these molecules have a higher affinity for the $\mathrm{p} 75^{\mathrm{NTR}}$ receptor than mature forms [14]. p $75^{\mathrm{NTR}}$ can form a complex with the sortilin receptor, which binds the N-terminal prodomain of pro-NGF, pro-BDNF, and pro-NT-3. Pro-NGF, which is the most well-defined proneurotrophin, has been implicated in the death of oligodendrocytes, spinal motor neurons, and corticospinal neurons in a p $75^{\mathrm{NTR}}$ dependent manner [36-38]. Upregulation of this molecule can occur in the injured state [12-14]. Thus, the fate of a cell may be determined by the relative abundance of either pro- or mature neurotrophins, or the interplay of Trk and p $75^{\mathrm{NTR}}$ receptor availability [33,39].

In the adult uninjured rat, neurons of the spinal cord do not generally produce the neurotrophins discussed in this paper, as evidenced by a lack of detectable mRNA transcript expression [40]. However, the expression of certain Trk receptors is abundant, as mRNA probes show TrkB and TrkC transcripts on the majority of neurons in the gray matter of the spinal cord at all levels examined [40-42]. TrkA mRNA was expressed on a small population of neurons scattered throughout the intermediate gray matter [43], and on small diameter nociceptive neurons of the dorsal root ganglia [44]. The presence of the mature form of the Trk receptors can allow for binding and retrograde transport of these factors.

In the context of spinal cord injury, the presence of Trk receptors may provide treatment targeted to specific spinal cord tracts. Figure 2 outlines neurotrophins which elicit growth responses from common motor (Figure 2A) and sensory (Figure 2B) tracts in the spinal cord (Clarke's nucleus (proprioceptive): [45]; Corticospinal tract: [46,47]; Fasciculus Cuneatus and Fasciculus Gracilis: [48-52]; Reticulospinal tract: [53,54]; Rubrospinal tract: [54-56]; Spinothalamic tract: [50,57,58]; Vestibulospinal tract: [53]). 


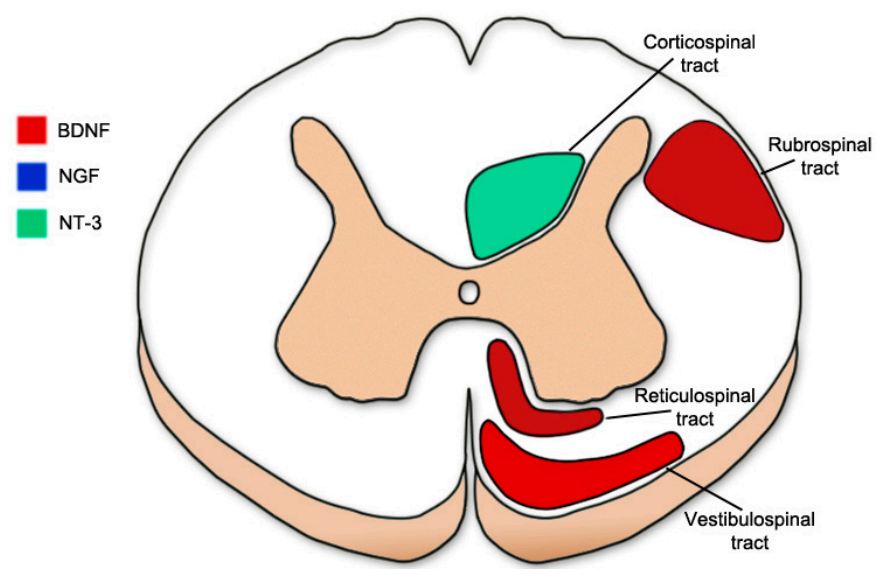

(A)

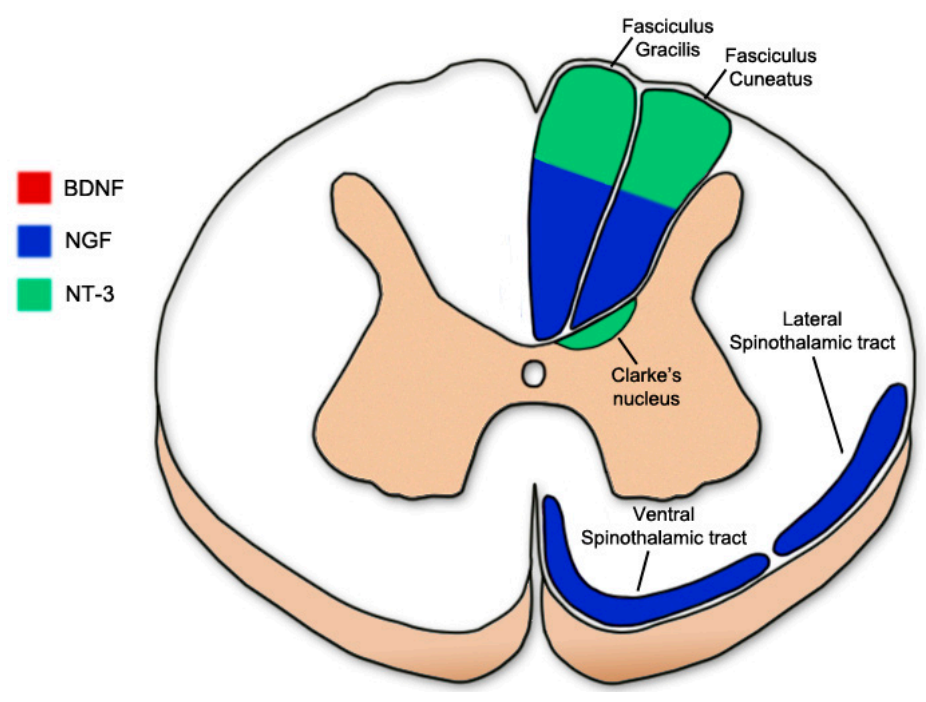

(B)

Figure 2. Common motor and sensory tract responsiveness to BDNF, NGF, and NT-3. (A) Common motor tracts; (B) Common sensory tracts. BDNF: Brain-derived neurotrophic factor, NGF: Nerve growth factor, NT-3: neurotrophin-3.

\section{Nerve Growth Factor}

Nerve growth factor (NGF) was the first neurotrophin discovered in the 1950s by Rita Levi-Montalcini and Viktor Hamburger in mouse sarcoma cultures in vitro [59]. Subsequent studies found a role for NGF in mediating survival and maturation of developing neurons in the peripheral nervous system (PNS). In the central nervous system (CNS), mature NGF has neuroprotective effects and can influence neural responses to injury on cell types that display NGF receptors, such as nociceptive sensory neurons (sympathetic and small diameter peripheral neurons), $\alpha$ motor neurons, and Schwann cells [60-64].

NGF binding with TrkA and $\mathrm{p} 75^{\mathrm{NTR}}$ receptors activates downstream signaling cascades such as MAPK/ERK, PI3K/Akt, and PLC- $\gamma$ pathways $[65,66]$. Activation of the MAPK/ERK and PI3K/Akt are both known to promote differentiation and survival of neurons (See Pearson et al., 2001, and Yuan et al., 2003 for reviews) [67,68]. PI3K/Akt phosphorylation of downstream proteins modifies the cell's cytoskeleton during motility and at the growth cone (See Yuan et al., 2003 for review) [68]. PLC- $\gamma$ pathways influence the intracellular release of $\mathrm{Ca}^{2+}$ by inositol-triphosphate dependent pathways [69]. In turn, this allows for the activation of calcium dependent proteins (e.g., $\mathrm{Ca}^{2+}$ 
calmodulin-dependent protein kinases, $\mathrm{Ca}^{2+}$ calmodulin associated targets) and the expression of ion channels and transcription factors [70,71].

The mechanism of NGF-induced axonal sprouting onto sensory neurons is one area of intense study. The expression of NGF within the spinal cord induces robust spouting of nociceptive axons and hyperalgesia [72]. Inhibitors to TrkA or NGF itself can reduce axonal sprouting of nociceptive axons $[73,74]$. Transplantation of grafts that express and secrete NGF into non-injured and injured rat spinal cords show increased nociceptive axon sprouting $[50,58,75,76]$. In addition, noradrenergic, cerulospinal, and cholinergic local motor axons sprouting is observed with NGF-expressing transplants $[58,76]$. NGF is also known to cause severed primary nociceptive sensory pathways to regenerate past the dorsal root entry zone (DREZ) and into the spinal cord [57,77].

The combination of other neurotrophins such as brain derived neurotrophic factor (BDNF), neurotrophin-3 (NT-3), and neurotrophin-4/5 (NT-4/5), or guidance molecules such as semaphorins, with NGF expression alter sprouting of primary sensory pathways in vivo [78-82]. These studies demonstrate improved axonal growth and some functional recovery of nociception [80-82] or hindlimb motor function $[78,79]$ in models of spinal cord injury.

As the main trophic effects of NGF are seen in small diameter sensory neurons, clinical trials have focused on issues such as diabetic or HIV-associated neuropathy. Phase II trials using recombinant human NGF (rhNGF) were promising, with improvements seen in sensory components of neurologic examinations and average daily pain assessments [83,84]. However, painful side effects of these trials revealed a dose limit of the rhNGF protein, and a follow-up Phase III trial failed to show any significant ameliorative effect [85]. Whether this was because of the smaller dosage, different study populations, or change in the formulation of the rhNGF was unclear, but its use was abandoned in this context by the manufacturer. A modified rhNGF is currently being evaluated in trials for neurotrophic keratitis by a different company, based on research showing it can promote corneal healing in rats and humans [86].

The nociceptive sprouting encouraged by NGF and accompanying pain reported in both animal models and clinical research has limited the use of this neurotrophin in regenerative studies of spinal cord injury $[87,88]$. However, research on chronic pain states, a common complaint in patients with $\mathrm{SCI}$, is ongoing. Fasinumab, a drug-based antibody against NGF, found significant improvement in pain scores in the study group [89].

Alternative therapeutic targets to promote neuroprotection could involve inhibiting signaling of proneurotrophins. Levels of pro-NGF are upregulated in the CNS after injury $[15,38]$, and it is believed to be apoptotic when $p 75^{\mathrm{NTR}}$ receptor levels are high $[14,90,91]$. Induction of cell death was attributed to pro-NGF in primary superior cervical ganglion cultures, smooth muscle cells, and PC12 cells $[14,90,91]$, and elevated levels of pro-NGF or pro-BDNF are observed in neurological disease states such as Alzheimer's, autism, or cognitive impairment associated with HIV [15,92-94]. Preclinical studies have demonstrated neuroprotection via genetic deletion of sortilin or introduction of pro-NGF specific antagonists in mice $[95,96]$. NGF antagonists have also demonstrated positive results after spinal cord injury [97], or amyotrophic lateral sclerosis (ALS) [98]. Other treatment options may include modulating the cleavage of pro-forms to encourage the presence of more mature neurotrophins.

\section{Brain-Derived Neurotrophic Factor}

Brain-derived Neurotrophic Factor exerts neuroprotective and growth-promoting effects on a variety of neuronal populations after injury. This is especially apparent in the rubrospinal, reticulospinal, and vestibulospinal tracts, as well as on the proprioceptive neurons of Clarke's nucleus in the spinal grey matter of the lumbar cord. Neuroprotective outcomes in particular may be attributed to downstream effects of TrkB receptor signaling. Pro-apoptotic molecules such as glycogen synthase kinase 3 (GSK-3), (Bcl-2 associated death promotor) Bad, and JNK are inhibited by TrkB signaling via the PI3-kinase and Akt pathway, allowing cells marked for death to survive. There are also studies showing that BDNF diminishes glutamate-induced apoptotic cell death [99]. 
BDNF is especially potent when protecting neurons of the rubrospinal tract, whose cells originate in the red nucleus. These neurons can undergo significant atrophy in the weeks following injury [1]. In situ hybridization for TrkB receptor expression found that nearly all rubrospinal neurons express this receptor. Infusion of BDNF via cannula in the vicinity of rubrospinal neurons (RSNs) fully prevented atrophy of these cells. This effect was also seen with NT-4/5, which has a similar binding pattern to TrkB receptors $[23,100,101]$. A significant increase in the percentage of cells showing mRNA transcripts of growth associated proteins such as GAP- 43 and T $\alpha 1$-tubulin was also found during BDNF application. A follow up study from the same group expressed BDNF via viral vector injection, and found a similar reversal of RSN atrophy and upregulation of regeneration associated genes [102]. These studies focused on acute injury, but RSNs can also be rescued at chronic time points. When a viral vector encoding BDNF was used to transduce these neurons at 18 months post-lesion, increased cell numbers and restoration of neuronal morphology was found in the red nucleus [103].

The neuroprotective effects of BDNF extend to the corticospinal motor system. Lu and colleagues explored both the influence of BDNF on corticospinal motor neuron and axonal growth of corticospinal tract (CST) axons. They found that grafting BDNF-secreting fibroblasts into an aspirated lesion in the cortical area increased survival of motor neurons in the spinal cord, but did not help with the growth of CST axons. Supporting these results, their study found robust TrkB receptor expression on the cell body and dendrites of corticospinal motor neurons, but not on their descending axons [4]. Neuroprotective effects of BDNF were also seen in the primary motor cortex after a T9 spinal cord lesion and grafting of mesenchymal stem cells engineered to secrete BDNF. Quantification of the number of fluorogold-labeled corticospinal neurons showed that BDNF could rescue these neurons when compared to T9 lesioned controls [104].

Studies of BDNF-secreting cells at the site of injury demonstrate that its protective effects can operate over a long distance. This is perhaps most impressively demonstrated by a 2010 study, which found neuroprotective effects in macaque pyramidal neurons when BDNF and NT-3 secreting cells were implanted at a C7 lesion site, a distance of about $10 \mathrm{~cm}$ from the cell body. Concurrent studies in rodents from this same group determined that BDNF, and not NT-3, was the factor influencing the survival of these neurons [105].

In addition to neuronal protection, BDNF can enhance regeneration and sprouting of injured axons in the spinal cord $[54,55,106,107]$, or increased remyelination of injured axons [107,108]. Several groups found that application of BDNF induces the upregulation of growth-associated genes such as GAP-43 and T-alpha-1-tubulin in neurons [55,109]. The upregulation of these genes may contribute to enhanced regeneration [110]. It is also thought that TrkB receptor activation of ERK pathway signaling may stimulate regeneration, as ERK can increase levels of cyclic AMP (cAMP), which may be partially responsible for the growth-promoting effects of conditioning lesions in the periphery $[110,111]$. As TrkB receptors are present on many neurons in the spinal cord, BDNF may act as a general inducer of sprouting and regeneration.

Several groups that reported protection of rubrospinal neurons also found axonal regeneration or regenerative sprouting of the rubrospinal tract [54,55,112-114]. A study by Jin and colleagues also noted increased growth of reticulospinal tract and vestibulospinal tract axons into a lesion cavity that contained BDNF-secreting fibroblasts [53]. Growth-promoting effects are also observed with raphespinal $[104,113]$ and coeruleospinal axons when BDNF administration is combined with fetal spinal cord transplants [113].

The effect of BDNF on the growth of corticospinal tract axons is mixed. The Bregman study found increased growth of corticospinal axons when BDNF-soaked gelfoam was applied to a lesion along with fetal spinal cord tissue transplant [113]. The sprouting of CST fibers and partial motor recovery was also seen with BDNF-secreting stem cells, or with transplanted cells and BDNF injected caudal to the lesion $[104,106]$. However, several other groups failed to see any significant growth of CST axons in response to BDNF $[4,115,116]$, in part perhaps due to the lack of TrkB receptors on these neurons. 
An interesting study by Hollis and colleagues found overexpressing TrkB on these neurons enhanced axonal expression and allowed CST axons to extend into BDNF-expressing cellular grafts [117].

TrkB is expressed abundantly in neurons of the spinal cord [41,42], potentially making BDNF and other members of the neurotrophin family that bind to it (e.g., NT-4/5) the most universally applicable molecules for injured motor tracts. The abundant expression of this receptor does come with a downside, however, as off-target effects such as pain or spasticity are sometimes associated with BDNF treatment [118-121]. TrkB is expressed on neurons of the dorsal horn, which receive nociceptive afferents. These neurons can also undergo upregulation of TrkB receptors during injury [122,123]. This may lead to BDNF-facilitated sprouting of C-fibers and increase of synaptic connections in pain pathways, which can then be prevented by blocking BDNF-TrkB signaling [119,120]. Recently, high concentrations of BDNF have been identified to alter chlorine homeostasis in neurons by downregulating the potassium-chlorine cotransporter (KCC2). Under such a condition, the down-regulation of KCC2 results in neuronal hyperexcitability and increased pain and spasticity [124-126]. As mentioned previously, another consideration is the relative abundance of the BDNF pro-form, which is upregulated in the injured state $[16,127,128]$, and is associated with neuronal death, neurite collapse, and process retraction in different populations of neurons $[127,129,130]$.

There is some conflicting evidence associated with BDNF treatment and its effects on pain and allodynia. Some authors found reversal of allodynia with BDNF treatment [131-133], or that pronociceptive effects may only occur in the non-injured state [134]. There is also speculation that BDNF's contribution to spasticity may only be induced by continuously high levels of this factor, and thus a regulated or transient dosage may solve this potential problem [135].

Dosage and penetrance are especially important when considering the use of BDNF in a clinical setting. Systemic use of BDNF in clinical trials has been unsuccessful both because of poor tissue penetrance and unfavorable side effects. BDNF crosses the blood-brain barrier only in minimal amounts, making peripheral administration inadequate for treatment, as seen in a large clinical trial seeking to treat amyotrophic lateral sclerosis (ALS) [136]. Methods of delivering BDNF directly to the CNS, such as intraventricular or intrathecal administration, were explored in further ALS trials, along with modification of the protein to increase tissue perfusion. However, BDNF was unable to adequately penetrate brain or spinal cord tissue beyond the superficial layers, failing to reach degenerating motor neurons in the cord $[137,138]$ Currently, methods such as intraparenchymal protein infusion and virus-mediated gene delivery are being explored to increase neurotrophin availability to appropriate neuronal populations [139-142].

\section{Neurotrophin-3}

The third member of the neurotrophin family, neurotrophin-3 (NT-3), was discovered by a group at the Max Planck Institute in 1990 [143]. This neurotrophin was more challenging to identify than NGF or BDNF because of lower protein abundance. However, researchers used conserved amino acid sequences from NGF and BDNF to create degenerative primers that allowed them to isolate mRNA for a protein with a similar structure and sequence, which they named NT-3. They found that NT-3 supported the survival of chick trigeminal mesencephalic neurons, a group of proprioceptive neurons that innervate skeletal muscle. They also found NT-3 in the liver and visceral organs [143]. This factor was isolated in parallel that same year by another group, who also found NT-3 in the kidney, lung, cerebellum, medulla, and hippocampus, and suggested that the broad distribution of this factor spoke to its role as a trophic factor for growing sympathetic and sensory neurons [144].

Later work found NT-3 to be important for the survival of several other groups of neurons. Studies in NT-3 null mutants found the developmental lack of a TrkC-expressing subpopulation of dorsal root ganglionneurons [145], as well as the elimination of muscle spindle 1a proprioceptive neurons [146]. Both studies resulted in abnormal movement patterns and very limited survival. In vitro, NT-3 also contributes to the survival of neurons of the hippocampus, sympathetic ganglia, dorsal root ganglia, and dopaminergic and GABAergic neurons of the ventral mesencephalon $[60,147]$. 
NT-3 is the most indiscriminate binding partner of the three mentioned neurotrophins, binding with lower affinity to TrkA, TrkB, and the p $75^{\mathrm{NTR}}$ receptor, and to the TrkC receptor with the highest affinity $[148,149]$. Thus far, NT-3 is the only neurotrophin isolated that binds with high affinity to the TrkC receptor. This is important because neurons of the corticospinal tract express the TrkC receptor [150]. The CST is the largest, and one of the most important, motor tracts that descend from the brain. It is involved in fine motor skills such as detailed hand and digit function. In the developing spinal cord, high levels of the TrkC receptor are found in the deep layers of the developing cortex, where CST neurons originate [151]. NT-3 mRNA is highly expressed in the developing spinal cord in motor neurons. Local injection of NT-3 into projected CST targets results in increased collateral sprouting of the CST, which is necessary for target finding, innervation, and synapse formation $[47,152]$. Though NT-3 expression is minimal in the adult spinal cord, the abundant expression of TrkC allows the responsiveness of the CST to mimic some of the observations seen during development. Grafts of cells engineered to express NT-3 into lesion sites allow for CST growth over short distances both at acute $[46,153,154]$ and chronic time points [155]. These studies also find a modest amount of functional recovery in either grid walking skills or locomotor scores.

Other studies using viral vector mediated delivery of NT-3 found regrowth of CST fibers when combined with nerve implants [156], or when injected into the rostral spinal cord [157], or the triceps muscle [158]. Collateral sprouting of CST axons can also be seen across the midline towards denervated motor neurons that express NT-3 $[159,160]$. CST axons seem to be the major benefactor of this neurotrophin, as a lack of sprouting has been found in other tracts, such as rubrospinal or cerulospinal [46].

Another advantage of NT-3 is that it is not associated with off-target effects such as pain or spasticity. In fact, NT-3 is currently being investigated in clinical trials as a treatment for peripheral neuropathies, which are often associated with chronic pain and allodynia. These trials are based on evidence that NT-3 prevents degeneration of peripheral sensory axons and can improve functional response in these neurons [161-163]. Significant improvement in the Neuropathy Impairment Score was seen in the NT-3 study group in one trial, and an increase in the number of small myelinated fibers assessed from sural nerve biopsies after treatment [163]. Subcutaneous administration of NT-3 is also being considered in Charcot-Marie Tooth neuropathy, as supported by animal studies [164].

\section{Conclusions}

The positive effects of neurotrophins on the growth, survival, and guidance of injured neurons of the spinal cord make them promising candidates for inclusion in treatment strategies. Thorough knowledge of their effects on specific populations of neurons will allow for the most efficient targeting, and awareness of receptor interaction can allow for fine tuning of dosage and avoidance of off-target effects. In combination with treatments that help ameliorate lesion environments such as stem cell grafts or nerve bridges, these factors have the potential to facilitate meaningful recovery after spinal cord injury.

Acknowledgments: This research is funded by grants from the Shriners Hospitals for Pediatric Research (grant SHC\#84050 and SHC\#8520) and the Department of Defense (grant \# SC140089).

Conflicts of Interest: The authors declare no conflict of interest.

\section{Abbreviations}

BDNF Brain-derived Neurotrophic Factor

NGF Nerve Growth Factor

NT-3 Neurotrophin-3

CST Corticospinal Tract 


\section{References}

1. Novikova, L.N.; Novikov, L.N.; Kellerth, J.O. Survival effects of BDNF and NT-3 on axotomized rubrospinal neurons depend on the temporal pattern of neurotrophin administration. Eur. J. Neurosci. 2000, 12, 776-780. [CrossRef] [PubMed]

2. Lewin, G.R.; Barde, Y.A. Physiology of the neurotrophins. Annu. Rev. Neurosci. 1996, 19, 289-317. [CrossRef] [PubMed]

3. Lohof, A.M.; Ip, N.Y.; Poo, M.M. Potentiation of developing neuromuscular synapses by the neurotrophins NT-3 and BDNF. Nature 1993, 363, 350-353. [CrossRef] [PubMed]

4. Lu, P.; Blesch, A.; Tuszynski, M.H. Neurotrophism without neurotropism: BDNF promotes survival but not growth of lesioned corticospinal neurons. J. Comp. Neurol. 2001, 436, 456-470. [CrossRef] [PubMed]

5. Kromer, L.F. Nerve growth factor treatment after brain injury prevents neuronal death. Science 1987, 235, 214-216. [CrossRef] [PubMed]

6. Levi-Montalcini, R. The nerve growth factor 35 years later. Science 1987, 237, 1154-1162. [CrossRef] [PubMed]

7. Davies, A.M. The role of neurotrophins in the developing nervous system. J. Neurobiol. 1994, 25, $1334-1348$. [CrossRef] [PubMed]

8. Barde, Y.A. The nerve growth factor family. Prog. Growth Factor Res. 1990, 2, 237-248. [CrossRef]

9. Thoenen, H. Neurotrophins and neuronal plasticity. Science 1995, 270, 593-598. [CrossRef] [PubMed]

10. Bradshaw, R.A.; Blundell, T.L.; Lapatto, R.; McDonald, N.Q.; Murray-Rust, J. Nerve growth factor revisited. Trends Biochem. Sci. 1993, 18, 48-52. [CrossRef]

11. Bibel, M.; Barde, Y.A. Neurotrophins: Key regulators of cell fate and cell shape in the vertebrate nervous system. Genes Dev. 2000, 14, 2919-2937. [CrossRef] [PubMed]

12. Seidah, N.G.; Benjannet, S.; Pareek, S.; Chretien, M.; Murphy, R.A. Cellular processing of the neurotrophin precursors of NT3 and BDNF by the mammalian proprotein convertases. FEBS Lett. 1996, 379, $247-250$. [CrossRef]

13. Seidah, N.G.; Benjannet, S.; Pareek, S.; Savaria, D.; Hamelin, J.; Goulet, B.; Laliberte, J.; Lazure, C.; Chretien, M.; Murphy, R.A. Cellular processing of the nerve growth factor precursor by the mammalian pro-protein convertases. Biochem. J. 1996, 314, 951-960. [CrossRef] [PubMed]

14. Lee, R.; Kermani, P.; Teng, K.K.; Hempstead, B.L. Regulation of cell survival by secreted proneurotrophins. Science 2001, 294, 1945-1948. [CrossRef] [PubMed]

15. Fahnestock, M.; Michalski, B.; Xu, B.; Coughlin, M.D. The precursor pro-nerve growth factor is the predominant form of nerve growth factor in brain and is increased in Alzheimer's disease. Mol. Cell. Neurosci. 2001, 18, 210-220. [CrossRef] [PubMed]

16. Pang, P.T.; Teng, H.K.; Zaitsev, E.; Woo, N.T.; Sakata, K.; Zhen, S.; Teng, K.K.; Yung, W.H.; Hempstead, B.L.; $\mathrm{Lu}, \mathrm{B}$. Cleavage of proBDNF by tPA/plasmin is essential for long-term hippocampal plasticity. Science 2004, 306, 487-491. [CrossRef] [PubMed]

17. Shamovsky, I.L.; Ross, G.M.; Riopelle, R.J.; Weaver, D.F. The interaction of neurotrophins with the p75NTR common neurotrophin receptor: A comprehensive molecular modeling study. Protein Sci. 1999, 8, $2223-2233$. [CrossRef] [PubMed]

18. He, X.L.; Garcia, K.C. Structure of nerve growth factor complexed with the shared neurotrophin receptor p75. Science 2004, 304, 870-875. [CrossRef] [PubMed]

19. Chao, M.V. Neurotrophins and their receptors: A convergence point for many signalling pathways. Nat. Rev. Neurosci. 2003, 4, 299-309. [CrossRef] [PubMed]

20. Huang, E.J.; Reichardt, L.F. Neurotrophins: Roles in neuronal development and function. Annu. Rev. Neurosci. 2001, 24, 677-736. [CrossRef] [PubMed]

21. Ultsch, M.H.; Wiesmann, C.; Simmons, L.C.; Henrich, J.; Yang, M.; Reilly, D.; Bass, S.H.; de Vos, A.M. Crystal structures of the neurotrophin-binding domain of TrkA, TrkB and TrkC. J. Mol. Biol. 1999, 290, 149-159. [CrossRef] [PubMed]

22. Squinto, S.P.; Stitt, T.N.; Aldrich, T.H.; Davis, S.; Bianco, S.M.; Radziejewski, C.; Glass, D.J.; Masiakowski, P.; Furth, M.E.; Valenzuela, D.M. trkB encodes a functional receptor for brain-derived neurotrophic factor and neurotrophin-3 but not nerve growth factor. Cell 1991, 65, 885-893. [CrossRef] 
23. Ip, N.Y.; Stitt, T.N.; Tapley, P.; Klein, R.; Glass, D.J.; Fandl, J.; Greene, L.A.; Barbacid, M.; Yancopoulos, G.D. Similarities and differences in the way neurotrophins interact with the Trk receptors in neuronal and nonneuronal cells. Neuron 1993, 10, 137-149. [CrossRef]

24. Blum, R.; Konnerth, A. Neurotrophin-mediated rapid signaling in the central nervous system: Mechanisms and functions. Physiology 2005, 20, 70-78. [CrossRef] [PubMed]

25. Benedetti, M.; Levi, A.; Chao, M.V. Differential expression of nerve growth factor receptors leads to altered binding affinity and neurotrophin responsiveness. Proc. Natl. Acad. Sci. USA 1993, 90, 7859-7863. [CrossRef] [PubMed]

26. Bibel, M.; Hoppe, E.; Barde, Y.A. Biochemical and functional interactions between the neurotrophin receptors trk and p75NTR. EMBO J. 1999, 18, 616-622. [CrossRef] [PubMed]

27. Mischel, P.S.; Smith, S.G.; Vining, E.R.; Valletta, J.S.; Mobley, W.C.; Reichardt, L.F. The extracellular domain of p75NTR is necessary to inhibit neurotrophin-3 signaling through TrkA. J. Biol. Chem. 2001, 276, 11294-11301. [CrossRef] [PubMed]

28. Hempstead, B.L.; Martin-Zanca, D.; Kaplan, D.R.; Parada, L.F.; Chao, M.V. High-affinity NGF binding requires coexpression of the trk proto-oncogene and the low-affinity NGF receptor. Nature 1991, 350, 678-683. [CrossRef] [PubMed]

29. Curtis, R.; Adryan, K.M.; Stark, J.L.; Park, J.S.; Compton, D.L.; Weskamp, G.; Huber, L.J.; Chao, M.V.; Jaenisch, R.; Lee, K.F. Differential role of the low affinity neurotrophin receptor (p75) in retrograde axonal transport of the neurotrophins. Neuron 1995, 14, 1201-1211. [CrossRef]

30. Makkerh, J.P.; Ceni, C.; Auld, D.S.; Vaillancourt, F.; Dorval, G.; Barker, P.A. p75 neurotrophin receptor reduces ligand-induced Trk receptor ubiquitination and delays Trk receptor internalization and degradation. EMBO Rep. 2005, 6, 936-941. [CrossRef] [PubMed]

31. Geetha, T.; Jiang, J.; Wooten, M.W. Lysine 63 polyubiquitination of the nerve growth factor receptor TrkA directs internalization and signaling. Mol. Cell. 2005, 20, 301-312. [CrossRef] [PubMed]

32. Roux, P.P.; Bhakar, A.L.; Kennedy, T.E.; Barker, P.A. The p75 neurotrophin receptor activates Akt (protein kinase B) through a phosphatidylinositol 3-kinase-dependent pathway. J. Biol. Chem. 2001, 276, 23097-23104. [CrossRef] [PubMed]

33. Kaplan, D.R.; Miller, F.D. Neurotrophin signal transduction in the nervous system. Curr. Opin. Neurobiol. 2000, 10, 381-391. [CrossRef]

34. Harrington, A.W.; Kim, J.Y.; Yoon, S.O. Activation of Rac GTPase by p75 is necessary for c-jun N-terminal kinase-mediated apoptosis. J. Neurosci. 2002, 22, 156-166. [PubMed]

35. Palmada, M.; Kanwal, S.; Rutkoski, N.J.; Gustafson-Brown, C.; Johnson, R.S.; Wisdom, R.; Carter, B.D. c-jun is essential for sympathetic neuronal death induced by NGF withdrawal but not by p75 activation. J. Cell. Biol. 2002, 158, 453-461. [CrossRef] [PubMed]

36. Beattie, M.S.; Harrington, A.W.; Lee, R.; Kim, J.Y.; Boyce, S.L.; Longo, F.M.; Bresnahan, J.C.; Hempstead, B.L.; Yoon, S.O. ProNGF induces p75-mediated death of oligodendrocytes following spinal cord injury. Neuron 2002, 36, 375-386. [CrossRef]

37. Domeniconi, M.; Hempstead, B.L.; Chao, M.V. Pro-NGF secreted by astrocytes promotes motor neuron cell death. Mol. Cell. Neurosci. 2007, 34, 271-279. [CrossRef] [PubMed]

38. Harrington, A.W.; Leiner, B.; Blechschmitt, C.; Arevalo, J.C.; Lee, R.; Morl, K.; Meyer, M.; Hempstead, B.L.; Yoon, S.O.; Giehl, K.M. Secreted proNGF is a pathophysiological death-inducing ligand after adult CNS injury. Proc. Natl. Acad. Sci. USA 2004, 101, 6226-6230. [CrossRef] [PubMed]

39. Masoudi, R.; Ioannou, M.S.; Coughlin, M.D.; Pagadala, P.; Neet, K.E.; Clewes, O.; Allen, S.J.; Dawbarn, D.; Fahnestock, M. Biological activity of nerve growth factor precursor is dependent upon relative levels of its receptors. J. Biol. Chem. 2009, 284, 18424-18433. [CrossRef] [PubMed]

40. Maisonpierre, P.C.; Belluscio, L.; Friedman, B.; Alderson, R.F.; Wiegand, S.J.; Furth, M.E.; Lindsay, R.M.; Yancopoulos, G.D. NT-3, BDNF, and NGF in the developing rat nervous system: Parallel as well as reciprocal patterns of expression. Neuron 1990, 5, 501-509. [CrossRef]

41. Armanini, M.P.; McMahon, S.B.; Sutherland, J.; Shelton, D.L.; Phillips, H.S. Truncated and catalytic isoforms of trkB are co-expressed in neurons of rat and mouse CNS. Eur. J. Neurosci. 1995, 7, 1403-1409. [CrossRef] [PubMed] 
42. Ernfors, P.; Rosario, C.M.; Merlio, J.P.; Grant, G.; Aldskogius, H.; Persson, H. Expression of mRNAs for neurotrophin receptors in the dorsal root ganglion and spinal cord during development and following peripheral or central axotomy. Brain Res. Mol. Brain Res. 1993, 17, 217-226. [CrossRef]

43. Michael, G.J.; Kaya, E.; Averill, S.; Rattray, M.; Clary, D.O.; Priestley, J.V. TrkA immunoreactive neurones in the rat spinal cord. J. Comp. Neurol. 1997, 385, 441-455. [CrossRef]

44. Mu, X.; Silos-Santiago, I.; Carroll, S.L.; Snider, W.D. Neurotrophin receptor genes are expressed in distinct patterns in developing dorsal root ganglia. J. Neurosci. 1993, 13, 4029-4041. [PubMed]

45. Himes, B.T.; Liu, Y.; Solowska, J.M.; Snyder, E.Y.; Fischer, I.; Tessler, A. Transplants of cells genetically modified to express neurotrophin-3 rescue axotomized Clarke's nucleus neurons after spinal cord hemisection in adult rats. J. Neurosci. Res. 2001, 65, 549-564. [CrossRef] [PubMed]

46. Grill, R.; Murai, K.; Blesch, A.; Gage, F.H.; Tuszynski, M.H. Cellular delivery of neurotrophin-3 promotes corticospinal axonal growth and partial functional recovery after spinal cord injury. J. Neurosci. 1997, 17, 5560-5572. [PubMed]

47. Schnell, L.; Schneider, R.; Kolbeck, R.; Barde, Y.A.; Schwab, M.E. Neurotrophin-3 enhances sprouting of corticospinal tract during development and after adult spinal cord lesion. Nature 1994, 367, 170-173. [CrossRef] [PubMed]

48. Otten, U.; Lorez, H.P.; Businger, F. Nerve growth factor antagonizes the neurotoxic action of capsaicin on primary sensory neurones. Nature 1983, 301, 515-517. [CrossRef] [PubMed]

49. Taylor, S.J.; Rosenzweig, E.S.; McDonald, J.W., 3rd; Sakiyama-Elbert, S.E. Delivery of neurotrophin-3 from fibrin enhances neuronal fiber sprouting after spinal cord injury. J. Control. Release 2006, 113, 226-235. [CrossRef] [PubMed]

50. Tuszynski, M.H.; Peterson, D.A.; Ray, J.; Baird, A.; Nakahara, Y.; Gage, F.H. Fibroblasts genetically modified to produce nerve growth factor induce robust neuritic ingrowth after grafting to the spinal cord. Exp. Neurol. 1994, 126, 1-14. [CrossRef] [PubMed]

51. Bradbury, E.J.; Khemani, S.; Von, R.; King; Priestley, J.V.; McMahon, S.B. NT-3 promotes growth of lesioned adult rat sensory axons ascending in the dorsal columns of the spinal cord. Eur. J. Neurosci. 1999, 11, 3873-3883. [CrossRef] [PubMed]

52. Lu, P.; Jones, L.L.; Snyder, E.Y.; Tuszynski, M.H. Neural stem cells constitutively secrete neurotrophic factors and promote extensive host axonal growth after spinal cord injury. Exp. Neurol. 2003, 181, 115-129. [CrossRef]

53. Jin, Y.; Fischer, I.; Tessler, A.; Houle, J.D. Transplants of fibroblasts genetically modified to express BDNF promote axonal regeneration from supraspinal neurons following chronic spinal cord injury. Exp. Neurol. 2002, 177, 265-275. [CrossRef] [PubMed]

54. Ye, J.H.; Houle, J.D. Treatment of the chronically injured spinal cord with neurotrophic factors can promote axonal regeneration from supraspinal neurons. Exp. Neurol. 1997, 143, 70-81. [CrossRef] [PubMed]

55. Kobayashi, N.R.; Fan, D.P.; Giehl, K.M.; Bedard, A.M.; Wiegand, S.J.; Tetzlaff, W. BDNF and NT-4/5 prevent atrophy of rat rubrospinal neurons after cervical axotomy, stimulate GAP-43 and Talpha1-tubulin mRNA expression, and promote axonal regeneration. J. Neurosci. 1997, 17, 9583-9595. [PubMed]

56. Liu, Y.; Kim, D.; Himes, B.T.; Chow, S.Y.; Schallert, T.; Murray, M.; Tessler, A.; Fischer, I. Transplants of fibroblasts genetically modified to express BDNF promote regeneration of adult rat rubrospinal axons and recovery of forelimb function. J. Neurosci. 1999, 19, 4370-4387. [PubMed]

57. Ramer, M.S.; Priestley, J.V.; McMahon, S.B. Functional regeneration of sensory axons into the adult spinal cord. Nature 2000, 403, 312-316. [CrossRef] [PubMed]

58. Tuszynski, M.H.; Gabriel, K.; Gage, F.H.; Suhr, S.; Meyer, S.; Rosetti, A. Nerve growth factor delivery by gene transfer induces differential outgrowth of sensory, motor, and noradrenergic neurites after adult spinal cord injury. Exp. Neurol. 1996, 137, 157-713. [CrossRef] [PubMed]

59. Levi-Montalcini, R.; Hamburger, V. Selective growth stimulating effects of mouse sarcoma on the sensory and sympathetic nervous system of the chick embryo. J. Exp. Zool. 1951, 116, 321-361. [CrossRef] [PubMed]

60. Ernfors, P.; Ebendal, T.; Olson, L.; Mouton, P.; Stromberg, I.; Persson, H. A cell line producing recombinant nerve growth factor evokes growth responses in intrinsic and grafted central cholinergic neurons. Proc. Natl. Acad. Sci. USA 1989, 86, 4756-4760. [CrossRef] [PubMed] 
61. Heumann, R.; Lindholm, D.; Bandtlow, C.; Meyer, M.; Radeke, M.J.; Misko, T.P.; Shooter, E.; Thoenen, H. Differential regulation of mRNA encoding nerve growth factor and its receptor in rat sciatic nerve during development, degeneration, and regeneration: Role of macrophages. Proc. Natl. Acad. Sci. USA 1987, 84, 8735-8739. [CrossRef] [PubMed]

62. Ruit, K.G.; Osborne, P.A.; Schmidt, R.E.; Johnson, E.M., Jr.; Snider, W.D. Nerve growth factor regulates sympathetic ganglion cell morphology and survival in the adult mouse. J. Neurosci. 1990, 10, 2412-2419. [PubMed]

63. Verge, V.M.; Richardson, P.M.; Benoit, R.; Riopelle, R.J. Histochemical characterization of sensory neurons with high-affinity receptors for nerve growth factor. J. Neurocytol. 1989, 18, 583-591. [CrossRef] [PubMed]

64. Wood, S.J.; Pritchard, J.; Sofroniew, M.V. Re-expression of Nerve Growth Factor Receptor after Axonal Injury Recapitulates a Developmental Event in Motor Neurons: Differential Regulation when Regeneration is Allowed or Prevented. Eur. J. Neurosci. 1990, 2, 650-657. [CrossRef] [PubMed]

65. Casaccia-Bonnefil, P.; Carter, B.D.; Dobrowsky, R.T.; Chao, M.V. Death of oligodendrocytes mediated by the interaction of nerve growth factor with its receptor p75. Nature 1996, 383, 716-719. [CrossRef] [PubMed]

66. Friedman, W.J.; Greene, L.A. Neurotrophin signaling via Trks and p75. Exp. Cell. Res. 1999, 253, $131-142$. [CrossRef] [PubMed]

67. Pearson, G.; Robinson, F.; Beers Gibson, T.; Xu, B.E.; Karandikar, M.; Berman, K.; Cobb, M.H. Mitogen-activated protein (MAP) kinase pathways: Regulation and physiological functions. Endocr. Rev. 2001, 22, 153-183. [CrossRef] [PubMed]

68. Yuan, X.B.; Jin, M.; Xu, X.; Song, Y.Q.; Wu, C.P.; Poo, M.M.; Duan, S. Signalling and crosstalk of Rho GTPases in mediating axon guidance. Nat. Cell. Biol. 2003, 5, 38-45. [CrossRef] [PubMed]

69. Rose, C.R.; Blum, R.; Pichler, B.; Lepier, A.; Kafitz, K.W.; Konnerth, A. Truncated TrkB-T1 mediates neurotrophin-evoked calcium signalling in glia cells. Nature 2003, 426, 74-78. [CrossRef] [PubMed]

70. Toledo-Aral, J.J.; Brehm, P.; Halegoua, S.; Mandel, G. A single pulse of nerve growth factor triggers long-term neuronal excitability through sodium channel gene induction. Neuron 1995, 14, 607-611. [CrossRef]

71. Minichiello, L.; Calella, A.M.; Medina, D.L.; Bonhoeffer, T.; Klein, R.; Korte, M. Mechanism of TrkB-mediated hippocampal long-term potentiation. Neuron 2002, 36, 121-137. [CrossRef]

72. Romero, M.I.; Rangappa, N.; Li, L.; Lightfoot, E.; Garry, M.G.; Smith, G.M. Extensive sprouting of sensory afferents and hyperalgesia induced by conditional expression of nerve growth factor in the adult spinal cord. J. Neurosci. 2000, 20, 4435-4445. [PubMed]

73. Christensen, M.D.; Hulsebosch, C.E. Spinal cord injury and anti-NGF treatment results in changes in CGRP density and distribution in the dorsal horn in the rat. Exp. Neurol. 1997, 147, 463-475. [CrossRef] [PubMed]

74. Gwak, Y.S.; Nam, T.S.; Paik, K.S.; Hulsebosch, C.E.; Leem, J.W. Attenuation of mechanical hyperalgesia following spinal cord injury by administration of antibodies to nerve growth factor in the rat. Neurosci. Lett. 2003, 336, 117-120. [CrossRef]

75. Tuszynski, M.H.; Weidner, N.; McCormack, M.; Miller, I.; Powell, H.; Conner, J. Grafts of genetically modified Schwann cells to the spinal cord: Survival, axon growth, and myelination. Cell. Transplant. 1998, 7, 187-196. [CrossRef]

76. Weidner, N.; Blesch, A.; Grill, R.J.; Tuszynski, M.H. Nerve growth factor-hypersecreting Schwann cell grafts augment and guide spinal cord axonal growth and remyelinate central nervous system axons in a phenotypically appropriate manner that correlates with expression of L1. J. Comp. Neurol. 1999, 413, 495-506. [CrossRef]

77. Romero, M.I.; Rangappa, N.; Garry, M.G.; Smith, G.M. Functional regeneration of chronically injured sensory afferents into adult spinal cord after neurotrophin gene therapy. J. Neurosci. 2001, 21, 8408-8416. [PubMed]

78. Feng, S.Q.; Kong, X.H.; Liu, Y.; Ban, D.X.; Ning, G.Z.; Chen, J.T.; Guo, S.F.; Wang, P. Regeneration of spinal cord with cell and gene therapy. Orthop. Surg. 2009, 1, 153-163. [CrossRef] [PubMed]

79. Gu, Y.L.; Yin, L.W.; Zhang, Z.; Liu, J.; Liu, S.J.; Zhang, L.F.; Wang, T.H. Neurotrophin expression in neural stem cells grafted acutely to transected spinal cord of adult rats linked to functional improvement. Cell. Mol. Neurobiol. 2012, 32, 1089-1097. [CrossRef] [PubMed]

80. Tang, X.Q.; Cai, J.; Nelson, K.D.; Peng, X.J.; Smith, G.M. Functional repair after dorsal root rhizotomy using nerve conduits and neurotrophic molecules. Eur. J. Neurosci. 2004, 20, 1211-1218. [CrossRef] [PubMed]

81. Tang, X.Q.; Heron, P.; Mashburn, C.; Smith, G.M. Targeting sensory axon regeneration in adult spinal cord. J. Neurosci. 2007, 27, 6068-6078. [CrossRef] [PubMed] 
82. Huang, M.C.; Lo, M.J.; Lin, Y.L.; Chang, S.E.; Huang, W.C.; Kuo, W.C.; Tsai, M.J.; Kuo, H.S.; Shih, Y.H.; Cheng, H. Functional recovery after the repair of transected cervical roots in the chronic stage of injury. J. Neurotrauma 2009, 26, 1795-1804. [CrossRef] [PubMed]

83. Apfel, S.C.; Kessler, J.A.; Adornato, B.T.; Litchy, W.J.; Sanders, C.; Rask, C.A. Recombinant human nerve growth factor in the treatment of diabetic polyneuropathy. NGF Study Group. Neurology 1998, 51, 695-702. [CrossRef] [PubMed]

84. McArthur, J.C.; Yiannoutsos, C.; Simpson, D.M.; Adornato, B.T.; Singer, E.J.; Hollander, H.; Marra, C.; Rubin, M.; Cohen, B.A.; Tucker, T.; et al. A phase II trial of nerve growth factor for sensory neuropathy associated with HIV infection. AIDS Clinical Trials Group Team 291. Neurology 2000, 54, 1080-1088. [CrossRef] [PubMed]

85. Apfel, S.C.; Schwartz, S.; Adornato, B.T.; Freeman, R.; Biton, V.; Rendell, M.; Vinik, A.; Giuliani, M.; Stevens, J.C.; Barbano, R.; et al. Efficacy and safety of recombinant human nerve growth factor in patients with diabetic polyneuropathy: A randomized controlled trial. rhNGF Clinical Investigator Group. JAMA 2000, 284, 2215-2221. [CrossRef] [PubMed]

86. Lambiase, A.; Manni, L.; Bonini, S.; Rama, P.; Micera, A.; Aloe, L. Nerve growth factor promotes corneal healing: Structural, biochemical, and molecular analyses of rat and human corneas. Invest. Ophthalmol. Vis. Sci. 2000, 41, 1063-1069. [PubMed]

87. Petty, B.G.; Cornblath, D.R.; Adornato, B.T.; Chaudhry, V.; Flexner, C.; Wachsman, M.; Sinicropi, D.; Burton, L.E.; Peroutka, S.J. The effect of systemically administered recombinant human nerve growth factor in healthy human subjects. Ann. Neurol. 1994, 36, 244-246. [CrossRef] [PubMed]

88. Shu, X.Q.; Mendell, L.M. Neurotrophins and hyperalgesia. Proc. Natl. Acad. Sci. USA 1999, 96, 7693-7696. [CrossRef] [PubMed]

89. Tiseo, P.J.; Kivitz, A.J.; Ervin, J.E.; Ren, H.; Mellis, S.J. Fasinumab (REGN475), an antibody against nerve growth factor for the treatment of pain: Results from a double-blind, placebo-controlled exploratory study in osteoarthritis of the knee. Pain 2014, 155, 1245-1252. [CrossRef] [PubMed]

90. Fahnestock, M.; Yu, G.; Coughlin, M.D. ProNGF: A neurotrophic or an apoptotic molecule? Prog. Brain Res. 2004, 146, 101-110. [PubMed]

91. Clewes, O.; Fahey, M.S.; Tyler, S.J.; Watson, J.J.; Seok, H.; Catania, C.; Cho, K.; Dawbarn, D.; Allen, S.J. Human ProNGF: Biological effects and binding profiles at TrkA, P75NTR and sortilin. J. Neurochem. 2008, 107, 1124-1135. [CrossRef] [PubMed]

92. Bachis, A.; Avdoshina, V.; Zecca, L.; Parsadanian, M.; Mocchetti, I. Human immunodeficiency virus type 1 alters brain-derived neurotrophic factor processing in neurons. J. Neurosci. 2012, 32, 9477-9484. [CrossRef] [PubMed]

93. Peng, S.; Wuu, J.; Mufson, E.J.; Fahnestock, M. Increased proNGF levels in subjects with mild cognitive impairment and mild Alzheimer disease. J. Neuropathol. Exp. Neurol. 2004, 63, 641-649. [CrossRef] [PubMed]

94. Garcia, K.L.; Yu, G.; Nicolini, C.; Michalski, B.; Garzon, D.J.; Chiu, V.S.; Tongiorgi, E.; Szatmari, P.; Fahnestock, M. Altered balance of proteolytic isoforms of pro-brain-derived neurotrophic factor in autism. J. Neuropathol. Exp. Neurol. 2012, 71, 289-297. [CrossRef] [PubMed]

95. Jansen, P.; Giehl, K.; Nyengaard, J.R.; Teng, K.; Lioubinski, O.; Sjoegaard, S.S.; Breiderhoff, T.; Gotthardt, M.; Lin, F.; Eilers, A.; et al. Roles for the pro-neurotrophin receptor sortilin in neuronal development, aging and brain injury. Nat. Neurosci. 2007, 10, 1449-1457. [CrossRef] [PubMed]

96. Volosin, M.; Trotter, C.; Cragnolini, A.; Kenchappa, R.S.; Light, M.; Hempstead, B.L.; Carter, B.D.; Friedman, W.J. Induction of proneurotrophins and activation of p75NTR-mediated apoptosis via neurotrophin receptor-interacting factor in hippocampal neurons after seizures. J. Neurosci. 2008, 28, 9870-9879. [CrossRef] [PubMed]

97. Tep, C.; Lim, T.H.; Ko, P.O.; Getahun, S.; Ryu, J.C.; Goettl, V.M.; Massa, S.M.; Basso, M.; Longo, F.M.; Yoon, S.O. Oral administration of a small molecule targeted to block proNGF binding to p75 promotes myelin sparing and functional recovery after spinal cord injury. J. Neurosci. 2013, 33, 397-410. [CrossRef] [PubMed]

98. Pehar, M.; Cassina, P.; Vargas, M.R.; Xie, Y.; Beckman, J.S.; Massa, S.M.; Longo, F.M.; Barbeito, L. Modulation of p75-dependent motor neuron death by a small non-peptidyl mimetic of the neurotrophin loop 1 domain. Eur. J. Neurosci. 2006, 24, 1575-1580. [CrossRef] [PubMed] 
99. Almeida, R.D.; Manadas, B.J.; Melo, C.V.; Gomes, J.R.; Mendes, C.S.; Graos, M.M.; Carvalho, R.F.; Carvalho, A.P.; Duarte, C.B. Neuroprotection by BDNF against glutamate-induced apoptotic cell death is mediated by ERK and PI3-kinase pathways. Cell. Death Differ. 2005, 12, 1329-1343. [CrossRef] [PubMed]

100. Berkemeier, L.R.; Winslow, J.W.; Kaplan, D.R.; Nikolics, K.; Goeddel, D.V.; Rosenthal, A. Neurotrophin-5: A novel neurotrophic factor that activates trk and trkB. Neuron 1991, 7, 857-866. [CrossRef]

101. Klein, R.; Lamballe, F.; Bryant, S.; Barbacid, M. The trkB tyrosine protein kinase is a receptor for neurotrophin-4. Neuron 1992, 8, 947-956. [CrossRef]

102. Kwon, B.K.; Liu, J.; Lam, C.; Plunet, W.; Oschipok, L.W.; Hauswirth, W.; Di Polo, A.; Blesch, A.; Tetzlaff, W. Brain-derived neurotrophic factor gene transfer with adeno-associated viral and lentiviral vectors prevents rubrospinal neuronal atrophy and stimulates regeneration-associated gene expression after acute cervical spinal cord injury. Spine (Phila. Pa 1976) 2007, 32, 1164-1173. [CrossRef] [PubMed]

103. Ruitenberg, M.J.; Blits, B.; Dijkhuizen, P.A.; te Beek, E.T.; Bakker, A.; van Heerikhuize, J.J.; Pool, C.W.; Hermens, W.T.; Boer, G.J.; Verhaagen, J. Adeno-associated viral vector-mediated gene transfer of brain-derived neurotrophic factor reverses atrophy of rubrospinal neurons following both acute and chronic spinal cord injury. Neurobiol. Dis. 2004, 15, 394-406. [CrossRef] [PubMed]

104. Sasaki, M.; Radtke, C.; Tan, A.M.; Zhao, P.; Hamada, H.; Houkin, K.; Honmou, O.; Kocsis, J.D. BDNF-hypersecreting human mesenchymal stem cells promote functional recovery, axonal sprouting, and protection of corticospinal neurons after spinal cord injury. J. Neurosci. 2009, 29, 14932-14941. [CrossRef]

105. Brock, J.H.; Rosenzweig, E.S.; Blesch, A.; Moseanko, R.; Havton, L.A.; Edgerton, V.R.; Tuszynski, M.H. Local and remote growth factor effects after primate spinal cord injury. J. Neurosci. 2010, 30, 9728-9737. [CrossRef]

106. Lu, P.; Blesch, A.; Graham, L.; Wang, Y.; Samara, R.; Banos, K.; Haringer, V.; Havton, L.; Weishaupt, N.; Bennett, D.; et al. Motor axonal regeneration after partial and complete spinal cord transection. J. Neurosci. 2012, 32, 8208-8218. [CrossRef] [PubMed]

107. Tuinstra, H.M.; Aviles, M.O.; Shin, S.; Holland, S.J.; Zelivyanskaya, M.L.; Fast, A.G.; Ko, S.Y.; Margul, D.J.; Bartels, A.K.; Boehler, R.M.; et al. Multifunctional, multichannel bridges that deliver neurotrophin encoding lentivirus for regeneration following spinal cord injury. Biomaterials 2012, 33, 1618-1626. [CrossRef] [PubMed]

108. Zhao, T.; Yan, W.; Xu, K.; Qi, Y.; Dai, X.; Shi, Z. Combined treatment with platelet-rich plasma and brain-derived neurotrophic factor-overexpressing bone marrow stromal cells supports axonal remyelination in a rat spinal cord hemi-section model. Cytotherapy 2013, 15, 792-804. [CrossRef] [PubMed]

109. Geremia, N.M.; Pettersson, L.M.; Hasmatali, J.C.; Hryciw, T.; Danielsen, N.; Schreyer, D.J.; Verge, V.M. Endogenous BDNF regulates induction of intrinsic neuronal growth programs in injured sensory neurons. Exp. Neurol. 2010, 223, 128-142. [CrossRef] [PubMed]

110. Yang, P.; Yang, Z. Enhancing intrinsic growth capacity promotes adult CNS regeneration. J. Neurol. Sci. 2012, 312, 1-6. [CrossRef] [PubMed]

111. Blesch, A.; Lu, P.; Tsukada, S.; Alto, L.T.; Roet, K.; Coppola, G.; Geschwind, D.; Tuszynski, M.H. Conditioning lesions before or after spinal cord injury recruit broad genetic mechanisms that sustain axonal regeneration: Superiority to camp-mediated effects. Exp. Neurol. 2012, 235, 162-173. [CrossRef] [PubMed]

112. Tobias, C.A.; Shumsky, J.S.; Shibata, M.; Tuszynski, M.H.; Fischer, I.; Tessler, A.; Murray, M. Delayed grafting of BDNF and NT-3 producing fibroblasts into the injured spinal cord stimulates sprouting, partially rescues axotomized red nucleus neurons from loss and atrophy, and provides limited regeneration. Exp. Neurol. 2003, 184, 97-113. [CrossRef]

113. Bregman, B.S.; McAtee, M.; Dai, H.N.; Kuhn, P.L. Neurotrophic factors increase axonal growth after spinal cord injury and transplantation in the adult rat. Exp. Neurol. 1997, 148, 475-494. [CrossRef] [PubMed]

114. Liu, Y.; Himes, B.T.; Murray, M.; Tessler, A.; Fischer, I. Grafts of BDNF-producing fibroblasts rescue axotomized rubrospinal neurons and prevent their atrophy. Exp. Neurol. 2002, 178, 150-164. [CrossRef] [PubMed]

115. Blesch, A.; Yang, H.; Weidner, N.; Hoang, A.; Otero, D. Axonal responses to cellularly delivered NT-4/5 after spinal cord injury. Mol. Cell. Neurosci. 2004, 27, 190-201. [CrossRef] [PubMed]

116. Hiebert, G.W.; Khodarahmi, K.; McGraw, J.; Steeves, J.D.; Tetzlaff, W. Brain-derived neurotrophic factor applied to the motor cortex promotes sprouting of corticospinal fibers but not regeneration into a peripheral nerve transplant. J. Neurosci. Res. 2002, 69, 160-168. [CrossRef] [PubMed]

117. Hollis, E.R., 2nd; Jamshidi, P.; Low, K.; Blesch, A.; Tuszynski, M.H. Induction of corticospinal regeneration by lentiviral trkB-induced Erk activation. Proc. Natl. Acad. Sci. USA 2009, 106, 7215-7220. [CrossRef] [PubMed] 
118. Boyce, V.S.; Park, J.; Gage, F.H.; Mendell, L.M. Differential effects of brain-derived neurotrophic factor and neurotrophin-3 on hindlimb function in paraplegic rats. Eur. J. Neurosci. 2012, 35, 221-232. [CrossRef] [PubMed]

119. Constandil, L.; Aguilera, R.; Goich, M.; Hernandez, A.; Alvarez, P.; Infante, C.; Pelissier, T. Involvement of spinal cord BDNF in the generation and maintenance of chronic neuropathic pain in rats. Brain Res. Bull. 2011, 86, 454-459. [CrossRef] [PubMed]

120. Endo, T.; Ajiki, T.; Inoue, H.; Kikuchi, M.; Yashiro, T.; Nakama, S.; Hoshino, Y.; Murakami, T.; Kobayashi, E. Early exercise in spinal cord injured rats induces allodynia through TrkB signaling. Biochem. Biophys. Res. Commun. 2009, 381, 339-344. [CrossRef] [PubMed]

121. Fouad, K.; Bennett, D.J.; Vavrek, R.; Blesch, A. Long-term viral brain-derived neurotrophic factor delivery promotes spasticity in rats with a cervical spinal cord hemisection. Front. Neurol. 2013. [CrossRef]

122. Kerr, B.J.; Bradbury, E.J.; Bennett, D.L.; Trivedi, P.M.; Dassan, P.; French, J.; Shelton, D.B.; McMahon, S.B.; Thompson, S.W. Brain-derived neurotrophic factor modulates nociceptive sensory inputs and NMDA-evoked responses in the rat spinal cord. J. Neurosci. 1999, 19, 5138-5148. [PubMed]

123. Lin, Y.T.; Ro, L.S.; Wang, H.L.; Chen, J.C. Up-regulation of dorsal root ganglia BDNF and trkB receptor in inflammatory pain: An in vivo and in vitro study. J. Neuroinflammation. 2011. [CrossRef] [PubMed]

124. Coull, J.A.; Boudreau, D.; Bachand, K.; Prescott, S.A.; Nault, F.; Sik, A.; de Koninck, P.; de Koninck, Y. Trans-synaptic shift in anion gradient in spinal lamina I neurons as a mechanism of neuropathic pain. Nature 2003, 424, 938-942. [CrossRef] [PubMed]

125. Ferrini, F.; de Koninck, Y. Microglia control neuronal network excitability via BDNF signalling. Neural Plast. 2013. [CrossRef] [PubMed]

126. Boulenguez, P.; Liabeuf, S.; Bos, R.; Bras, H.; Jean-Xavier, C.; Brocard, C.; Stil, A.; Darbon, P.; Cattaert, D.; Delpire, E.; et al. Down-regulation of the potassium-chloride cotransporter KCC2 contributes to spasticity after spinal cord injury. Nat. Med. 2010, 16, 302-307. [CrossRef] [PubMed]

127. Yang, J.; Siao, C.J.; Nagappan, G.; Marinic, T.; Jing, D.; McGrath, K.; Chen, Z.Y.; Mark, W.; Tessarollo, L.; Lee, F.S.; et al. Neuronal release of proBDNF. Nat. Neurosci. 2009, 12, 113-115. [CrossRef] [PubMed]

128. Koshimizu, H.; Kiyosue, K.; Hara, T.; Hazama, S.; Suzuki, S.; Uegaki, K.; Nagappan, G.; Zaitsev, E.; Hirokawa, T.; Tatsu, Y.; et al. Multiple functions of precursor BDNF to CNS neurons: Negative regulation of neurite growth, spine formation and cell survival. Mol. Brain 2009. [CrossRef] [PubMed]

129. Sun, M.M.; Zhang, M.Z.; Chen, Y.; Li, S.L.; Zhang, W.; Ya, G.W.; Chen, K.S. Effect of PTEN antisense oligonucleotide on oesophageal squamous cell carcinoma cell lines. J. Int. Med. Res. 2012, 40, 2098-2108. [CrossRef] [PubMed]

130. Teng, H.K.; Teng, K.K.; Lee, R.; Wright, S.; Tevar, S.; Almeida, R.D.; Kermani, P.; Torkin, R.; Chen, Z.Y.; Lee, F.S.; et al. ProBDNF induces neuronal apoptosis via activation of a receptor complex of p75NTR and sortilin. J. Neurosci. 2005, 25, 5455-5463. [CrossRef] [PubMed]

131. Eaton, M.J.; Blits, B.; Ruitenberg, M.J.; Verhaagen, J.; Oudega, M. Amelioration of chronic neuropathic pain after partial nerve injury by adeno-associated viral (AAV) vector-mediated over-expression of BDNF in the rat spinal cord. Gene Ther. 2002, 9, 1387-1395. [CrossRef]

132. Hayashida, K.; Clayton, B.A.; Johnson, J.E.; Eisenach, J.C. Brain derived nerve growth factor induces spinal noradrenergic fiber sprouting and enhances clonidine analgesia following nerve injury in rats. Pain 2008, 136, 348-355. [CrossRef]

133. Hutchinson, K.J.; Gomez-Pinilla, F.; Crowe, M.J.; Ying, Z.; Basso, D.M. Three exercise paradigms differentially improve sensory recovery after spinal cord contusion in rats. Brain 2004, 127, 1403-1414. [CrossRef] [PubMed]

134. Garraway, S.M.; Huie, J.R. Spinal Plasticity and Behavior: BDNF-Induced Neuromodulation in Uninjured and Injured Spinal Cord. Neural Plast. 2016. [CrossRef] [PubMed]

135. Ankeny, D.P.; McTigue, D.M.; Guan, Z.; Yan, Q.; Kinstler, O.; Stokes, B.T.; Jakeman, L.B. Pegylated brain-derived neurotrophic factor shows improved distribution into the spinal cord and stimulates locomotor activity and morphological changes after injury. Exp. Neurol. 2001, 170, 85-100. [CrossRef] [PubMed]

136. A controlled trial of recombinant methionyl human BDNF in ALS: The BDNF Study Group (Phase III). Neurology 1999, 52, 1427-1433. 
137. Beck, M.; Flachenecker, P.; Magnus, T.; Giess, R.; Reiners, K.; Toyka, K.V.; Naumann, M. Autonomic dysfunction in ALS: A preliminary study on the effects of intrathecal BDNF. Amyotroph. Lateral Scler. Other Motor Neuron Disord. 2005, 6, 100-103. [CrossRef] [PubMed]

138. Ochs, G.; Penn, R.D.; York, M.; Giess, R.; Beck, M.; Tonn, J.; Haigh, J.; Malta, E.; Traub, M.; Sendtner, M.; et al. A phase I/II trial of recombinant methionyl human brain derived neurotrophic factor administered by intrathecal infusion to patients with amyotrophic lateral sclerosis. Amyotroph. Lateral Scler. Other Motor Neuron Disord. 2000, 1, 201-206. [CrossRef] [PubMed]

139. Herzog, C.D.; Brown, L.; Gammon, D.; Kruegel, B.; Lin, R.; Wilson, A.; Bolton, A.; Printz, M.; Gasmi, M.; Bishop, K.M.; et al. Expression, bioactivity, and safety 1 year after adeno-associated viral vector type 2-mediated delivery of neurturin to the monkey nigrostriatal system support cere-120 for Parkinson's disease. Neurosurgery 2009, 64, 602-613. [CrossRef] [PubMed]

140. Nutt, J.G.; Burchiel, K.J.; Comella, C.L.; Jankovic, J.; Lang, A.E.; Laws, E.R., Jr.; Lozano, A.M.; Penn, R.D.; Simpson, R.K., Jr.; Stacy, M.; et al. Randomized, double-blind trial of glial cell line-derived neurotrophic factor (GDNF) in PD. Neurology 2003, 60, 69-73. [CrossRef] [PubMed]

141. Marks, W.J., Jr.; Bartus, R.T.; Siffert, J.; Davis, C.S.; Lozano, A.; Boulis, N.; Vitek, J.; Stacy, M.; Turner, D.; Verhagen, L.; et al. Gene delivery of AAV2-neurturin for Parkinson's disease: A double-blind, randomised, controlled trial. Lancet Neurol. 2010, 9, 1164-1172. [CrossRef]

142. Tuszynski, M.H.; Thal, L.; Pay, M.; Salmon, D.P.; U, H.S.; Bakay, R.; Patel, P.; Blesch, A.; Vahlsing, H.L.; Ho, G.; et al. A phase 1 clinical trial of nerve growth factor gene therapy for Alzheimer disease. Nat. Med. 2005, 11, 551-555. [CrossRef] [PubMed]

143. Hohn, A.; Leibrock, J.; Bailey, K.; Barde, Y.A. Identification and characterization of a novel member of the nerve growth factor/brain-derived neurotrophic factor family. Nature 1990, 344, 339-341. [CrossRef] [PubMed]

144. Rosenthal, A.; Goeddel, D.V.; Nguyen, T.; Lewis, M.; Shih, A.; Laramee, G.R.; Nikolics, K.; Winslow, J.W. Primary structure and biological activity of a novel human neurotrophic factor. Neuron 1990, 4, 767-773. [CrossRef]

145. Tessarollo, L.; Vogel, K.S.; Palko, M.E.; Reid, S.W.; Parada, L.F. Targeted mutation in the neurotrophin-3 gene results in loss of muscle sensory neurons. Proc. Natl. Acad. Sci. USA 1994, 91, 11844-11848. [CrossRef] [PubMed]

146. Klein, R.; Silos-Santiago, I.; Smeyne, R.J.; Lira, S.A.; Brambilla, R.; Bryant, S.; Zhang, L.; Snider, W.D.; Barbacid, M. Disruption of the neurotrophin-3 receptor gene trkC eliminates la muscle afferents and results in abnormal movements. Nature 1994, 368, 249-251. [CrossRef] [PubMed]

147. Kucera, J.; Fan, G.; Jaenisch, R.; Linnarsson, S.; Ernfors, P. Dependence of developing group Ia afferents on neurotrophin-3. J. Comp. Neurol. 1995, 363, 307-320. [CrossRef] [PubMed]

148. Klein, R.; Nanduri, V.; Jing, S.A.; Lamballe, F.; Tapley, P.; Bryant, S.; Cordon-Cardo, C.; Jones, K.R.; Reichardt, L.F.; Barbacid, M. The trkB tyrosine protein kinase is a receptor for brain-derived neurotrophic factor and neurotrophin-3. Cell 1991, 66, 395-403. [CrossRef]

149. Lamballe, F.; Klein, R.; Barbacid, M. trkC, a new member of the TRK family of tyrosine protein kinases, is a receptor for neurotrophin-3. Cell 1991, 66, 967-979. [CrossRef]

150. Maisonpierre, P.C.; Belluscio, L.; Squinto, S.; Ip, N.Y.; Furth, M.E.; Lindsay, R.M.; Yancopoulos, G.D. Neurotrophin-3: A neurotrophic factor related to NGF and BDNF. Science 1990, 247, 1446-1451. [CrossRef] [PubMed]

151. Ringstedt, T.; Lagercrantz, H.; Persson, H. Expression of members of the TRK family in the developing postnatal rat brain. Brain Res. Dev. Brain Res. 1993, 72, 119-131. [CrossRef]

152. Schreyer, D.J.; Jones, E.G. Growth and target finding by axons of the corticospinal tract in prenatal and postnatal rats. Neuroscience 1982, 7, 1837-1853. [CrossRef]

153. Ma, Y.H.; Zhang, Y.; Cao, L.; Su, J.C.; Wang, Z.W.; Xu, A.B.; Zhang, S.C. Effect of neurotrophin-3 genetically modified olfactory ensheathing cells transplantation on spinal cord injury. Cell Transplant. 2010, 19, 167-177. [CrossRef] [PubMed]

154. Shang, A.J.; Hong, S.Q.; Xu, Q.; Wang, H.Y.; Yang, Y.; Wang, Z.F.; Xu, B.N.; Jiang, X.D.; Xu, R.X. NT-3-secreting human umbilical cord mesenchymal stromal cell transplantation for the treatment of acute spinal cord injury in rats. Brain Res. 2011, 1391, 102-113. [CrossRef] [PubMed] 
155. Tuszynski, M.H.; Grill, R.; Jones, L.L.; Brant, A.; Blesch, A.; Low, K.; Lacroix, S.; Lu, P. NT-3 gene delivery elicits growth of chronically injured corticospinal axons and modestly improves functional deficits after chronic scar resection. Exp. Neurol. 2003, 181, 47-56. [CrossRef]

156. Blits, B.; Dijkhuizen, P.A.; Boer, G.J.; Verhaagen, J. Intercostal nerve implants transduced with an adenoviral vector encoding neurotrophin-3 promote regrowth of injured rat corticospinal tract fibers and improve hindlimb function. Exp. Neurol. 2000, 164, 25-37. [CrossRef] [PubMed]

157. Weishaupt, N.; Mason, A.L.; Hurd, C.; May, Z.; Zmyslowski, D.C.; Galleguillos, D.; Sipione, S.; Fouad, K. Vector-induced NT-3 expression in rats promotes collateral growth of injured corticospinal tract axons far rostral to a spinal cord injury. Neuroscience 2014, 272, 65-75. [CrossRef] [PubMed]

158. Fortun, J.; Puzis, R.; Pearse, D.D.; Gage, F.H.; Bunge, M.B. Muscle injection of AAV-NT3 promotes anatomical reorganization of CST axons and improves behavioral outcome following SCI. J. Neurotrauma 2009, 26, 941-953. [CrossRef] [PubMed]

159. Chen, Q.; Zhou, L.; Shine, H.D. Expression of neurotrophin-3 promotes axonal plasticity in the acute but not chronic injured spinal cord. J. Neurotrauma. 2006, 23, 1254-1260. [CrossRef] [PubMed]

160. Zhou, L.; Baumgartner, B.J.; Hill-Felberg, S.J.; McGowen, L.R.; Shine, H.D. Neurotrophin-3 expressed in situ induces axonal plasticity in the adult injured spinal cord. J. Neurosci. 2003, 23, 1424-1431. [PubMed]

161. Helgren, M.E.; Cliffer, K.D.; Torrento, K.; Cavnor, C.; Curtis, R.; DiStefano, P.S.; Wiegand, S.J.; Lindsay, R.M. Neurotrophin-3 administration attenuates deficits of pyridoxine-induced large-fiber sensory neuropathy. J. Neurosci. 1997, 17, 372-382. [PubMed]

162. Gao, W.Q.; Dybdal, N.; Shinsky, N.; Murnane, A.; Schmelzer, C.; Siegel, M.; Keller, G.; Hefti, F.; Phillips, H.S.; Winslow, J.W. Neurotrophin-3 reverses experimental cisplatin-induced peripheral sensory neuropathy. Ann. Neurol. 1995, 38, 30-37. [CrossRef] [PubMed]

163. Sahenk, Z.; Nagaraja, H.N.; McCracken, B.S.; King, W.M.; Freimer, M.L.; Cedarbaum, J.M.; Mendell, J.R. NT-3 promotes nerve regeneration and sensory improvement in CMT1A mouse models and in patients. Neurology 2005, 65, 681-689. [CrossRef] [PubMed]

164. Sahenk, Z.; Galloway, G.; Clark, K.R.; Malik, V.; Rodino-Klapac, L.R.; Kaspar, B.K.; Chen, L.; Braganza, C.; Montgomery, C.; Mendell, J.R. AAV1.NT-3 gene therapy for charcot-marie-tooth neuropathy. Mol. Ther. 2014, 22, 511-521. [CrossRef] [PubMed] 